\title{
A comparison of the distribution and sources of organic matter in surface sediments collected from northwestern and southwestern plateau lakes in China
}

\author{
Jidun FANG, ${ }^{1}$ Fengchang WU, ${ }^{2 *}$ Yongqiang XIONG,${ }^{3}$ Shuping WANG, ${ }^{1}$ Hongjun YANG ${ }^{1}$ \\ ${ }^{1}$ Shandong Key Laboratory of Eco-Environmental Science for Yellow River Delta, Binzhou University, Shandong Province; ${ }^{2}$ State \\ Key Laboratory of Environmental Criteria and Risk Assessment, Chinese Research Academy of Environmental Sciences, Beijing \\ 100012; ${ }^{3}$ State Key Laboratory of Organic Geochemistry, Guangzhou Institute of Geochemistry, Chinese Academy of Sciences, \\ Guangzhou 510640, China
}

\begin{abstract}
Surface lacustrine sediments from six plateau lakes in China were analysed for total organic carbon (TOC), total nitrogen, $\delta^{13} \mathrm{C}_{\text {org }}, \delta^{15} \mathrm{~N}_{\text {total }}$, aliphatic hydrocarbons, fatty acids (FAs), and alkanols. The FAs and alkanols were fractionated into free and bound subfractions to facilitate investigation of their sources. Higher average TOC levels were observed in sediments from southwestern plateau lakes than in those from northwestern plateau lakes. The sediments from the southwestern plateau lakes may have been contaminated with petroleum hydrocarbons from anthropogenic activities. The molecular compositions of n-alkanes, n-alkanols, and FAs extracted from the lacustrine sediments showed different responses to environmental changes. Most of the n-alkanol and FA distributions were dominated by short-chain components originating from algae and bacteria. However, the presence of longchain n-alkanes indicate the presence of predominantly terrestrial organic matter (OM) in the sediment samples from the northwestern plateau lakes in China, suggesting that secondary components derived from post-depositional microbial activity were key contributors to the n-alkanols and FAs. Aquatic FAs derived from algae and anaerobic bacteria were a major component of the sedimentary OM and accounted for $65.1-90.2 \%$ of the total lipid concentrations.
\end{abstract}

Key words: Lacustrine sediments; total organic carbon; $n$-alkanes; $n$-alkanols; fatty acids; factors; sources.

Received: December 2016. Accepted: May 2017.

\section{INTRODUCTION}

Lake sediments contain a diverse range of lipid compounds. Because lipids are derived primarily from organisms living within lakes and their catchments, differences in lipid composition directly reflect differences in lake and catchment biota. In recent years, many new compounds have been identified in lacustrine sediments, and terrestrial higher plants and microalgae have been identified as sources of these lipids (Meyers, 2003). Some compounds degrade slowly or are transformed to more stable chemical structures; these compounds can be used as biomarkers when investigating the sources of organic matter $(\mathrm{OM})$ in sediments. Although they make up only a small percentage of bulk OM (Meyers, 2003), lipids have been widely used in geochemical studies of lacustrine sediments (Muri et al., 2004).

Sedimentary OM can be used to carry out paleoclimatic and paleoenvironmental reconstructions in lakes. Bulk OM parameters, e.g., total organic carbon (TOC), total nitrogen (TN), $\mathrm{C}_{\text {org }} / \mathrm{N}_{\mathrm{TN}}$, and $\delta^{13} \mathrm{C}_{\text {org }}$ (the stable $\mathrm{C}$ isotopic composition of organic carbon), have been widely used to determine OM sources (Rieley et al., 1991; Meyers, 1997, 2003). Aliphatic hydrocarbons (AHs) and fatty acids (FAs) in lacustrine sediments are commonly used to provide information on the origins of $\mathrm{OM}$, as well as on its state of preservation or degree of alteration, the nature of the substrate and the physicochemical conditions that control these factors (Meyers, 2003). Numerous studies have utilized information derived from AHs and FAs to estimate the relative contributions of terrestrial, algal or bacterial OM to the total OM pool in lacustrine sediments (Meyers, 2003; Xiong et al., 2010). Although alkanol distributions in lacustrine sediments have not been as widely applied in palaeolimnological reconstruction as AHs or FAs, they contain equally useful information about OM sources. Aquatic algae and bacteria generally have $n$-alkanol distributions that are dominated by $\mathrm{C}_{16}$ to $\mathrm{C}_{22}$ components (Robinson et al., 1984; Volkman et al., 1999), whereas $n$-alkanols from terrestrial plants are usually characterized by an abundance of $\mathrm{C}_{26}, \mathrm{C}_{28}$, and $\mathrm{C}_{30}$ homologues (Meyers, 2003).

The distribution and sources of lipids in lacustrine sediments may be influenced by many factors, including the quantities of industrial effluent and domestic sewage that enter the lakes, mean annual precipitation (MAP), mean annual surface water temperatures (MAWT), light intensities, nutrient salt levels, $\mathrm{pH}$ values and total dissolved solids (TDS) concentrations (Cao et al., 2011). Light intensity, day length, and nutrient salt levels are important 
factors that regulate the growth of phytoplankton. Longer day length and higher light intensity have been shown to be associated with higher biomass production than shorter days and lower light intensities; moreover, complete utilization of nitrate and phosphate occurs in a shorter amount of time under conditions involving longer day lengths and higher light intensities (Meseck et al., 2005).

The northwestern plateau is a unique tectonic feature. The bedrock within its catchment consists of sedimentary and metamorphic rocks, as well as small amounts of igneous rocks. Because of the high altitude (1000-2000 m), the vegetation in the catchment areas of most of the lakes consists mainly of alpine meadows and alpine steppes. The vegetation on the plateau includes predominantly C3 plants and varies from swampy meadow vegetation to mountain shrubs; $\mathrm{C} 4$ plants play only a minor role. The southwestern plateau is the middle tier of the eastern slope of the Himalayas. It is a complex geomorphological unit that is characterized by low latitudes and high altitudes $(1000-2000 \mathrm{~m})$, as well as large altitude gradients. This area is affected by both the southeastern (Pacific Ocean) and southwestern (Indian Ocean) monsoons. The main vegetation is subtropical evergreen broad-leaved forest, which co-exists or is mixed with deciduous broad-leaved forest. Superimposed on the natural climatic changes are more recent anthropogenic influences that have been caused by industrialization and changes in agricultural practices. It is important to differentiate between anthropogenic impacts and those caused by natural environmental changes.

This project provides a comprehensive study of the composition, preservation and origin of bulk $\mathrm{OM}$ and lipids in lacustrine sediments from six lakes. The lakes include northwestern and southwestern plateau lakes, which cover a range of latitudes extending from $25^{\circ} 47^{\prime}(\mathrm{N})$ to $41^{\circ} 58^{\prime}(\mathrm{N})$. Natural factors that may influence the composition of sedimentary OM, such as light intensity, MAWT, MAP, pH, and TDS, differ among the lakes. To identify the spatial distribution and changes in the source of sedimentary $\mathrm{OM}$, along with the factors that influence the different plateau lakes, TOC and TN concentrations, $\delta^{13} \mathrm{C}_{\text {org }}$ and $\delta^{15} \mathrm{~N}_{\text {total }}$ values, and the compositions of biomarkers (AHs, $n$-alkanols and FAs) in the surface sediments were analysed.

\section{METHODS}

\section{Lake selection and sediment collection}

Six lakes (Lake Hongfeng, Lake Chenghai, Lake Erhai, Lake Bosten, Lake Sugan and Lake Qinghai) were selected from the southwestern and northwestern plateaus in China. The parameters MAWT, MAP, pH and TDS clearly differ among these study lakes, due to their widely varying latitudes (which range from $25^{\circ} 47^{\prime}(\mathrm{N})$ to $41^{\circ} 58^{\prime}$ (N)) and the effects of human activities. Four sediment cores were collected from the centre of each lake in 2014 using a piston-percussion corer fitted with $58 \mathrm{~mm}$ i.d. Perspex tubes. The cores were sectioned into $1-\mathrm{cm}$ intervals and freeze-dried immediately after collection. To increase the representativeness of the studied samples, the surface sections $(0-1 \mathrm{~cm})$ of all four sediment cores from each lake were combined for analysis.

\section{Elemental and stable isotope analyses}

Subsamples for elemental (TOC and TN) and bulk stable isotope composition analyses were acidified with $1 \mathrm{M}$ $\mathrm{HCl}$ before analysis to remove carbonates. The concentrations of TOC and TN, as well as the $\mathrm{C}_{\text {org }} / \mathrm{N}_{\text {total }}$ (atomic) ratios, were determined using a CHNS Vario E1 III elemental analyser. Carbon and nitrogen isotope analyses were conducted on a Thermo Finnigan Delta Plus XL mass spectrometer connected to a Flash EA 1112 elemental analyser via a Finnigan MAT ConFlo III interface. The stable isotopic ratios $\delta^{13} \mathrm{C}_{\text {org }}$ and $\delta^{15} \mathrm{~N}_{\text {total }}$ are reported relative to the Vienna Pee Dee Belemnite and air standards, respectively. The instrument analytical precision was $0.1 \%$ for $\delta^{13} \mathrm{C}_{\text {org }}$ and $0.2 \%$ for $\delta^{15} \mathrm{~N}_{\text {total }}$.

\section{Extraction and fractionation of free and bound lipids}

The samples were Soxhlet extracted for $72 \mathrm{~h}$ with $\mathrm{CH}_{2} \mathrm{Cl}_{2} / \mathrm{MeOH}(9: 1 \mathrm{v} / \mathrm{v})$. Sulfur was removed through the addition of activated $\mathrm{Cu}$. The free lipids were fractionated using silica gel-alumina column chromatography $(50 \mathrm{~mm}$ $\times 5 \mathrm{~mm}$ i.d.). The saturated hydrocarbons were eluted with $20 \mathrm{~mL}$ of hexane, followed by the free alkanols and free fatty acid (FFA) fractions, which were successively eluted using $20 \mathrm{~mL}$ of $20 \%$ ethyl acetate (EtOAc) in hexane and $20 \mathrm{~mL}$ of methanol $(\mathrm{MeOH})$. The extracts were saponified with $0.5 \mathrm{M} \mathrm{KOH}$ in $\mathrm{MeOH}$ under reflux for $2 \mathrm{~h}$ to release the ester-bound lipids. The mixtures were centrifuged, and the supernatant was decanted. The bound alkanols were extracted with $n$-hexane/Et $\mathrm{O}(9: 1 \mathrm{v} / \mathrm{v})$. After acidification to $\mathrm{pH} 1$ through the addition of $\mathrm{HCl}$, the bound fatty acids (BFAs) were extracted with $\mathrm{CH}_{2} \mathrm{Cl}_{2}$. All fractions were analysed using gas chromatography (GC) and $\mathrm{GC}$ mass spectrometry (GC-MS). Prior to the GC and GC-MS analyses, the free and bound alkanol fractions were derivatized with acetic anhydride/pyridine $(1: 1 \mathrm{v} / \mathrm{v})$. The FFA and BFA fractions were methylated with $\mathrm{MeOH}$ $\left(100^{\circ} \mathrm{C}, 1 \mathrm{~h}\right)$ to convert them to FA methyl esters.

\section{Gas chromatography and gas chromatography-mass spectrometry}

GC was conducted using a Finnigan Trace GC instrument equipped with an HP-5 fused silica column $(50 \mathrm{~m} \times$ $0.32 \mathrm{~mm} \times 0.25 \mu \mathrm{m}$ film thickness). The carrier gas used 
was $\mathrm{N}_{2}$, and the oven temperature program was $70^{\circ} \mathrm{C}(2$ $\min$ ) to $290^{\circ} \mathrm{C}$ (held $30 \mathrm{~min}$ ) at $3^{\circ} \mathrm{C} \mathrm{min}^{-1}$. The GC-MS analyses were performed using a Finnigan Platform II mass spectrometer coupled to a Hewlett-Packard (HP) 6890 GC instrument and an HP-5 fused silica column (50 $\mathrm{m} \times 0.32$ $\mathrm{mm} \times 0.25 \mu \mathrm{m}$ film thickness $)$. The temperature program was $70^{\circ} \mathrm{C}(5 \mathrm{~min})$ to $290^{\circ} \mathrm{C}$ (held $30 \mathrm{~min}$ ) at $3^{\circ} \mathrm{C} \mathrm{min}^{-1}$. The $n$-alkanes, alkanols, and FAs were quantified through integration of the peak areas in total ion current (TIC) plots. Perdeuterated eicosane was used as an internal standard, and the response factor for individual AHs, alkanols, and FAs relative to the standard was assumed to be 1.0.

\section{RESULTS}

\section{Bulk composition of organic matter}

The TOC contents varied between 2.0 and $4.9 \%$ for the sedimentary samples. The TOC contents were generally higher in the sediments obtained from the southwestern plateau lakes than those obtained from the northwestern plateau lakes in China (Fig. 1). The $\mathrm{C}_{\text {org }} / \mathrm{N}_{\text {total }}$ values ranged between 8.2 and 11.4 for the sedimentary OM. The $\delta^{13} \mathrm{C}_{\text {org }}$ values for most of the lakes varied between $-29.4 \%$ and $-24.0 \%$. The only exception was the sediment from Lake Sugan, which had $\delta^{13} \mathrm{C}_{\text {org }}$ values of $-18.8 \%$. In this study, the $\delta^{15} \mathrm{~N}_{\text {total }}$ values ranged from +4.6 to $+8.7 \%$.

\section{Composition and distribution of free and bound lipids}

Nineteen AHs, 15 n-alkanols and 32 FAs were identified. The FAs included normal saturated FAs $\left(\mathrm{C}_{12: 0}\right.$ to $\mathrm{C}_{28: 0}$ ), branched FAs (e.g., iso- $\mathrm{C}_{15: 0}$ and anteiso- $\mathrm{C}_{15: 0}$ ), and monounsaturated FAs (e.g., $\mathrm{C}_{16: 1}$ and $\left.\mathrm{C}_{18: 1}\right)$. The compounds were divided into several subgroups according to their terrestrial, algal, bacterial, and mixed origins.

\section{Aliphatic hydrocarbons}

The AHs in the sedimentary samples were dominated by $n$-alkanes ranging from $\mathrm{C}_{15}$ to $\mathrm{C}_{31}$. As shown in Fig. 2,

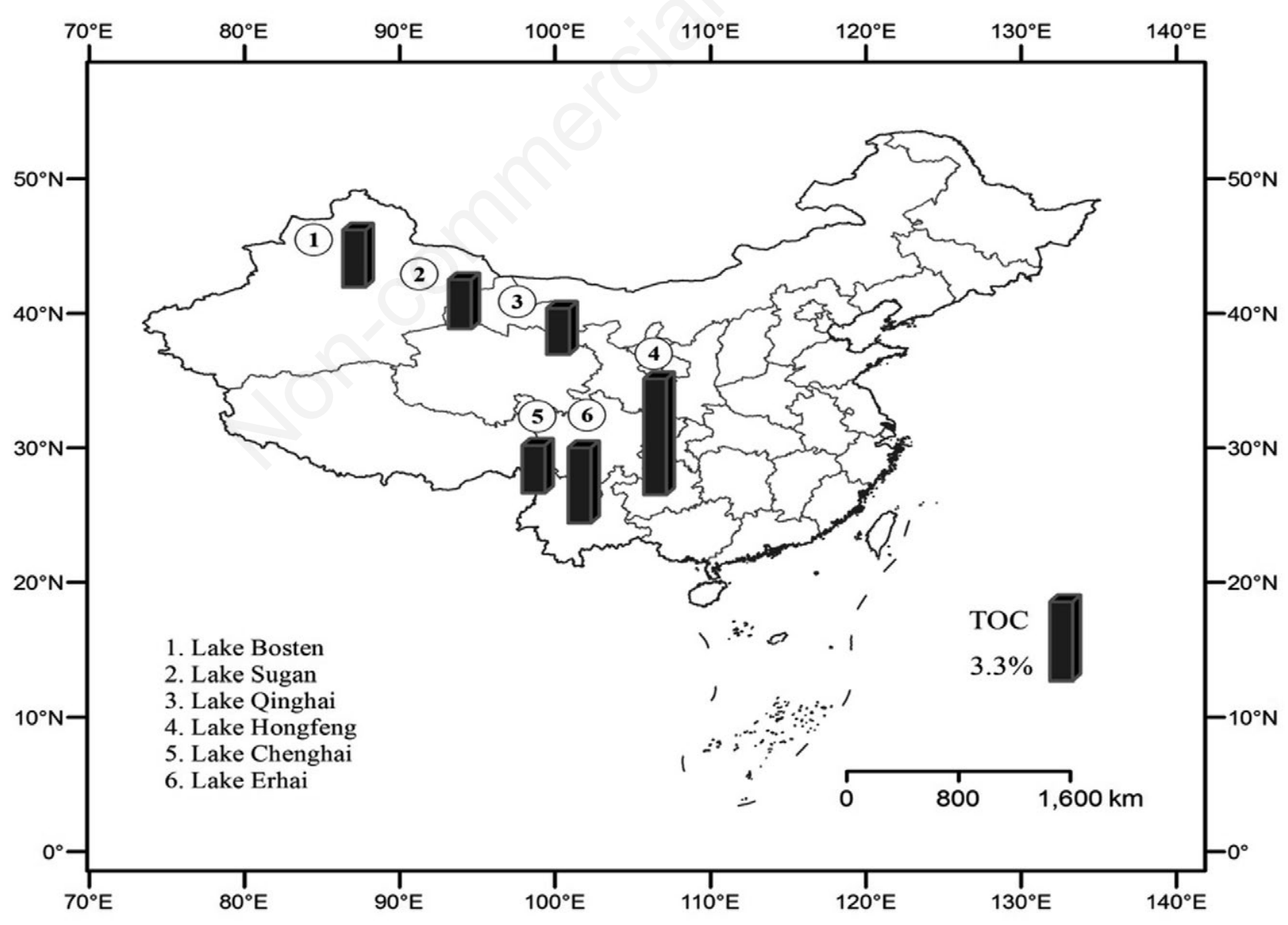

Fig. 1. Sketch map of PR China showing the locations and TOC distributions in the surface sediments from northwestern and southwestern plateau lakes in China. 
the distributions of $n$-alkanes differed considerably among the lakes studied. The $n$-alkanes found in the sediments obtained from the southwestern plateau lakes were generally dominated by plankton-derived $\mathrm{C}_{15}-\mathrm{C}_{20}$ components with a maximum around $\mathrm{C}_{17}$ or $\mathrm{C}_{18}$. In contrast, the $\mathrm{C}_{25^{-}}$ $\mathrm{C}_{31} n$-alkanes derived from terrestrial higher plants peaking at $\mathrm{C}_{27}, \mathrm{C}_{29}$, or $\mathrm{C}_{31}$ dominated the sedimentary $n$-alkanes from the northwestern plateau lakes. Pristane $(\mathrm{Pr})$ and phytane $(\mathrm{Ph})$, which are products of the geological alteration of phytol and other natural isoprenoid products, were found in all samples.

\section{Fatty acids}

FAs were the most abundant lipids, and they made up $80.1-91.1 \%$ of the total lipids (TL) by concentration. TL represents the sum of all lipid compounds measured, including AHs, alkanols, and FAs. The concentrations of BFAs ranged from 3569.8 to $10,776.4 \mu \mathrm{g} \mathrm{gOC}_{-1}$, and the FFA concentrations ranged from 80.9 to $590.0 \mu \mathrm{g} \mathrm{gOC}_{-1}$. The FA composition showed that the saturated fatty acids (SFAs) were dominated by $\mathrm{C}_{14: 0}, \mathrm{C}_{16: 0}$, and $\mathrm{C}_{18: 0}$ in the sediment samples. Except for the BFAs in the sediment from
Lake Hongfeng, which display a maximum at $i-\mathrm{C}_{15: 0}$ (accounting for $39.3 \%$ of total BFA), the TICs for the FFAs and BFAs in all other samples were characterized by a unimodal distribution pattern, and the short-chain $n-\mathrm{C}_{16: 0}$ component was predominant (Fig. 3); $n$ - $\mathrm{C}_{16: 0}$ constituted $24.9-40.6 \%$ and $19.0-30.1 \%$ of the FFAs and BFAs, respectively. Iso-acids in the range $\mathrm{C}_{12}$ to $\mathrm{C}_{18}$ occurred in the BFAs and those from $\mathrm{C}_{13}$ to $\mathrm{C}_{17}$ occurred in the FFAs. On the other hand, anteiso-acids ranging from $\mathrm{C}_{13}$ to $\mathrm{C}_{17}$ were found in the BFAs, and only anteiso- $\mathrm{C}_{15}$ was found to occur in the FFAs. Polyunsaturated fatty acids (PUFAs) are normally associated with algae. However, the PUFA concentrations were below detectable levels in all of our samples.

\section{Aliphatic alkanols}

The $n$-alkanol fractions extracted from the lake sediments had carbon chain lengths that ranged from $\mathrm{C}_{14}$ to $\mathrm{C}_{28}$, and a strong predominance of even over odd chains was noted (Fig. 4). The concentration of free $n$-alkanols ranged from 58.0 to $492.7 \mu \mathrm{gOC}_{-1}$ (1.0-8.2\% of TLs), whereas the bound $n$-alkanols varied from 142.0 to 382.6
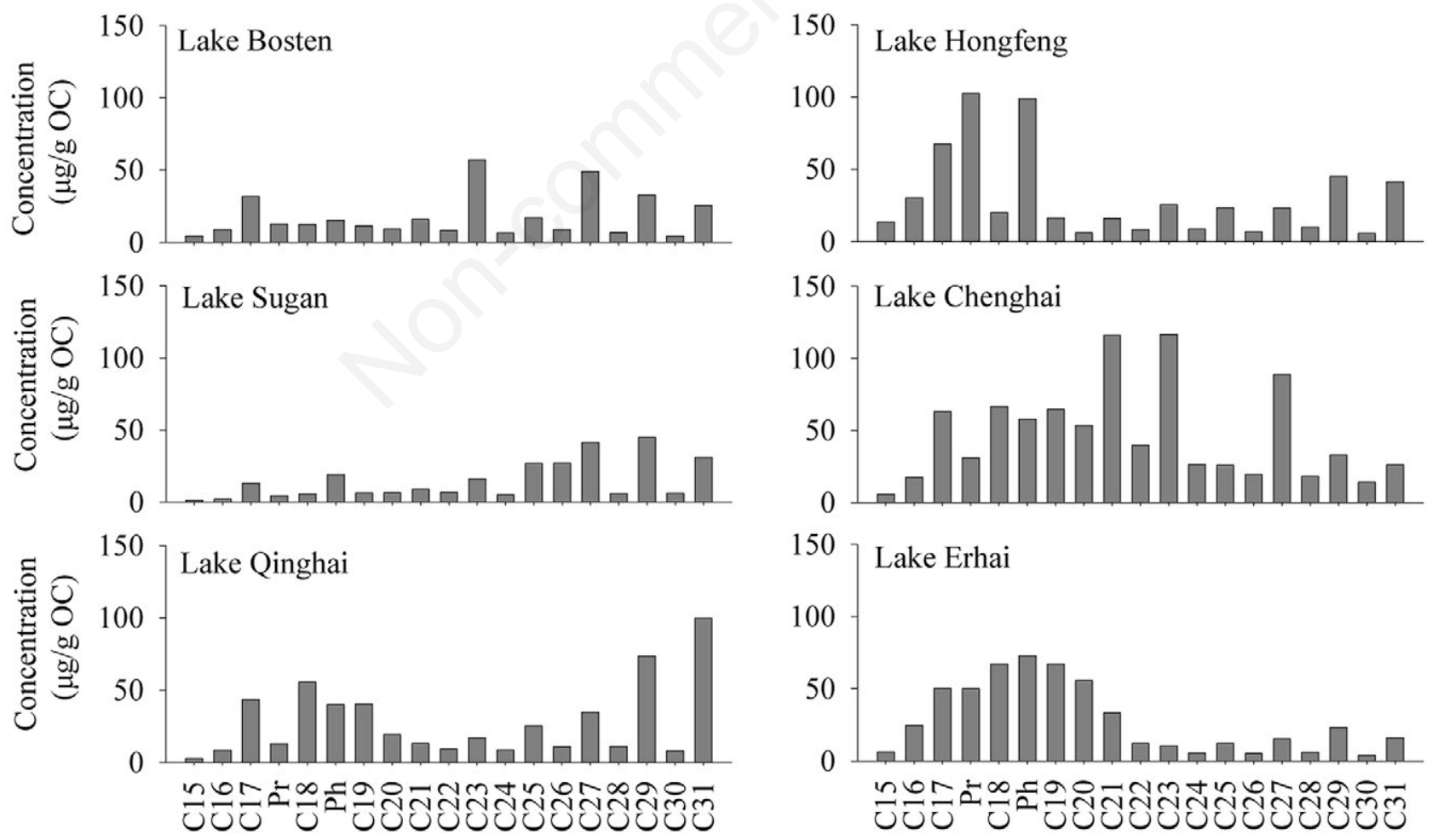

Carbon number Northwestem plateau lakes

Carbon number Southwestem plateau lakes

Fig. 2. Distribution of aliphatic hydrocarbons in the surface sediments. 
$\mu \mathrm{g} \mathrm{gOC}_{-1}(2.6-8.6 \%$ of TLs). There were marked differences between the distributions of free and bound $n$-alkanols. For example, the bound $n$-alkanols were dominated by short-chain compounds $\left(\mathrm{C}_{14}-\mathrm{C}_{22}\right)$, and many samples were not found to contain any long-chain compounds $\left(\mathrm{C}_{24}-\mathrm{C}_{28}\right)$. However, in some of the sediment samples, the free $n$-alkanols displayed a bimodal distribution with a maximum at $\mathrm{C}_{18}$ or $\mathrm{C}_{22}$, a secondary maximum at $\mathrm{C}_{26}$ or $\mathrm{C}_{28}$ (Fig. 4) and a strong predominance of even-chain lengths.

\section{DISCUSSION}

\section{Sources of organic matter}

The parameters $\mathrm{C}_{\text {org }} \mathrm{N}_{\text {total }}, \delta^{13} \mathrm{C}_{\text {org }}$ and $\delta^{15} \mathrm{~N}_{\text {total }}$, which are useful bulk indicators of the sources of organic matter examined in paleolimnological reconstructions, can be used to assess the relative contribution of allochthonous versus autochthonous components. The ratio of $\mathrm{C}_{\text {org }} / \mathrm{N}_{\text {total }}$ usually ranges from 5 to 8 in plankton and bacteria and from 20 to 100 in terrestrial organic matter (Jasper and Gagosian, 1989). Tab. 1 shows that the $\mathrm{C}_{\text {org }} / \mathrm{N}_{\text {total }}$ ratios range from 8.2 to 11.4 and are intermediate between values that are characteristic of autochthonous and allochthonous inputs of organic matter, indicating a mixed source for the organic matter found in the sediment samples. The $\mathrm{C}_{\text {org }} / \mathrm{N}_{\text {total }}$ ratios are closer to the range associated with typical autochthonous sources than to that associated with allochthonous sources. This result indicates that the sedimentary OM from the northwestern and southwestern plateau lakes in China is derived mainly from aquatic algae and bacteria. The $\delta^{13} \mathrm{C}_{\text {org }}$ values of most of the sediment samples obtained from the studied lakes varied between $-29.4 \%$ and $-24.0 \%$ (Tab. 1), and these values are characteristic of both lacustrine algae and $\mathrm{C}_{3}$ land plants (Meyers, 2003). The only exception was the sediment from Lake Sugan, which had $\delta^{13} \mathrm{C}_{\text {org }}$ values of $-18.8 \%$. The heavier $\delta^{13} \mathrm{C}_{\text {org }}$ values from Lake Sugan may have been caused by the higher TDS values noted at that lake (Tab. 1). The $\delta^{13} \mathrm{C}$ values of $\mathrm{OM}$ from aquatic sources in the lake respond to the carbon isotopic composition of the lake water dissolved inorganic carbon (DIC) source, and high $\delta^{13} \mathrm{C}_{\mathrm{DIC}}$ values are associated with increasing TDS values (Li et al., 2012).

Terrigenous detrital OM is generally characterized by a low $\delta^{15} \mathrm{~N}_{\text {total }}(+0.5 \%$ ) signature, whereas aquatic components have a relatively high $\delta^{15} \mathrm{~N}_{\text {total }}(+8.5 \%)$ value (Thornton and McManus, 1994). In addition, $\delta^{15} \mathrm{~N}_{\text {total }}$ values can also be used to investigate the sources and mechanisms of pollution. For example, typical $\delta^{15} \mathrm{~N}_{\text {total }}$ values range from -2 to $+4 \%$ o for commercial fertilizers, +3 to
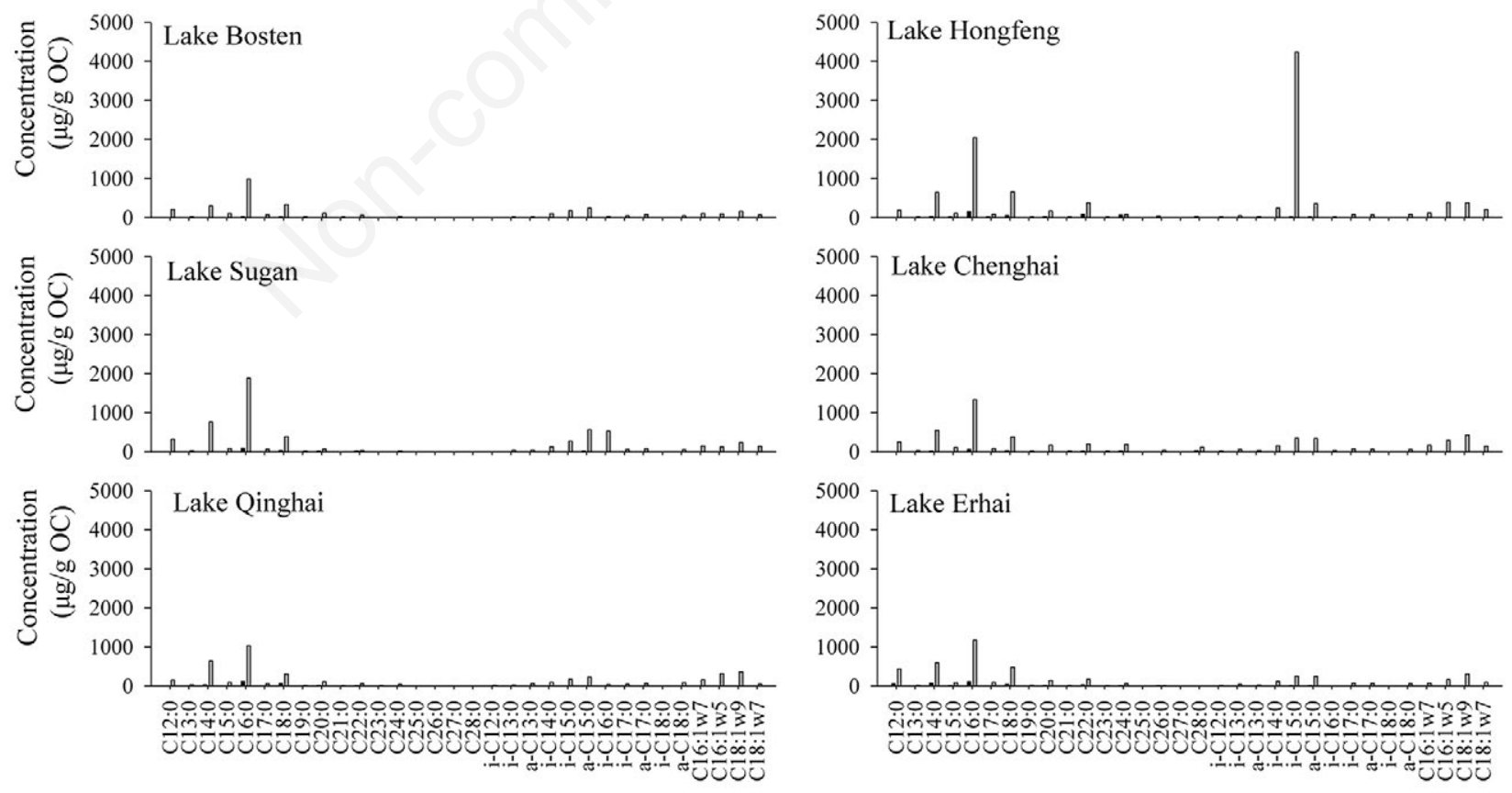

Free fatty acids

Bound fatty acids

Carbon numbers

Northwestern plateau lakes

Carbon numbers

Southwestern plateau lakes

Fig. 3. Distribution of fatty acids in the surface sediments. 
$+8 \%$ for soil organic nitrogen nitrate and +10 to $+20 \%$ o for human and animal waste nitrate (Aravena et al., 1993). In this study, the $\delta^{15} \mathrm{~N}_{\text {total }}$ values ranged from +4.6 to $+8.7 \%$ (Tab. 1). These values provide further evidence for a mixed source of OM, and they indicate that the inputs from algae and bacteria were dominant in these surface sediment samples. A few common ratios, such as TAR $_{\mathrm{HC}}\left(\mathrm{TAR}_{\mathrm{HC}}=\left(\mathrm{C}_{27}+\mathrm{C}_{29}+\mathrm{C}_{31}\right) /\left(\mathrm{C}_{15}+\mathrm{C}_{17}+\mathrm{C}_{19}\right)\right) \mathrm{n}-$ alkanes, $\mathrm{TAR}_{\mathrm{AK}}\left(\mathrm{TAR}_{\mathrm{AK}}=\left(\mathrm{C}_{24}+\mathrm{C}_{26}+\mathrm{C}_{28}\right) /\left(\mathrm{C}_{14}+\mathrm{C}_{16}+\right.\right.$ $\left.\left.\mathrm{C}_{18}\right)\right)$ n-alkanols, and $\mathrm{TAR}_{\mathrm{FA}}\left(\mathrm{TAR}_{\mathrm{FA}}=\left(n-\mathrm{C}_{24: 0}+n-\mathrm{C}_{26: 0}+\right.\right.$
$\left.\left.n-\mathrm{C}_{28: 0}\right) /\left(n-\mathrm{C}_{14: 0}+n-\mathrm{C}_{16: 0}+n-\mathrm{C}_{18: 0}\right)\right)$ fatty acids (Meyers, 2003; Fang et al., 2014), served as molecular geochemical proxies for land-derived versus algal contributions of lipids in this study. Tab. 2 displays the values of TAR $\mathrm{HC}_{\mathrm{HC}}$, $\mathrm{TAR}_{\mathrm{AK}}$, and $\mathrm{TAR}_{\mathrm{FA}}$ for the $\mathrm{OM}$ in the sedimentary samples. The n-alkanes are less susceptible to degradation than other components of organic matter in sediments; thus, the n-alkane distributions are more useful for identifying sources of organic matter. Terrigenous OM is commonly richer in $n$-alkanes than algal and bacteria material,

Tab. 1. Basic data and total organic matter indexes for six plateau lakes in China.

\begin{tabular}{|c|c|c|c|c|c|c|c|c|c|c|c|c|c|}
\hline Lake & $\begin{array}{c}\text { Sampling } \\
\text { date }\end{array}$ & $\begin{array}{l}\text { Lake } \\
\text { area* } \\
\left(\mathrm{km}^{2}\right)\end{array}$ & $\begin{array}{c}\text { MAWT* } \\
\left({ }^{\circ} \mathrm{C}\right)\end{array}$ & $\begin{array}{l}\text { Sampling } \\
\text { site depth } \\
\text { (m) }\end{array}$ & $\begin{array}{c}\text { Catchment } \\
\text { area* } \\
\left(\mathrm{km}^{2}\right)\end{array}$ & $\begin{array}{l}\text { TDS* } \\
\left(\mathrm{g} \mathrm{L}^{-1}\right)\end{array}$ & $\begin{array}{c}\text { MAP* } \\
(\mathrm{mm})\end{array}$ & $\mathrm{pH}^{*}$ & $\begin{array}{l}\text { TOC } \\
(\%)\end{array}$ & $\begin{array}{l}\mathrm{TN} \\
(\%)\end{array}$ & $\mathrm{C}_{\text {org }} / \mathbf{N}_{\text {total }}$ & $\delta^{13} \mathrm{C}_{\text {org }}$ & $\delta^{15} N_{\text {total }}$ \\
\hline Lake Bosten & 9-Sep & 992.0 & 7.9 & 16.5 & 22000 & 1.9 & 62.3 & 8.6 & 2.4 & 0.3 & 9.2 & -26.9 & 4.6 \\
\hline Lake Sugan & 13-Sep & 108.0 & 2.7 & 6.1 & 7000 & 31.8 & 77.6 & 8.5 & 2.1 & 0.3 & 8.2 & -18.8 & 5.3 \\
\hline Lake Qinghai & 16-Sep & 4340.0 & 5.8 & 28.2 & 29661 & 15.5 & 336.6 & 9.2 & 2.0 & 0.3 & 8.9 & -28.1 & 6.0 \\
\hline Lake Hongfeng & 21-Sep & 57.2 & 14.1 & 45.0 & 1596 & 0.2 & 1200.6 & 8.5 & 4.9 & 0.5 & 11.4 & -29.4 & 8.7 \\
\hline Lake Chenghai & 25-Sep & 77.2 & 18.7 & 36.9 & 318 & 1.0 & 725.5 & 9.2 & 2.0 & 0.3 & 9.2 & -26.5 & 5.2 \\
\hline Lake Erhai & 28-Sep & 249.0 & 15.3 & 21.5 & 2470 & 0.3 & 1100.4 & 8.4 & 3.2 & 0.4 & 8.8 & -26.8 & 4.7 \\
\hline
\end{tabular}

MAWT, mean annual surface water temperatures; TDS, total dissolved solids; MAP, mean annual precipitation; TOC, total organic carbon; TN, total nitrogen; *obtained from the China Lake Scientific Database and published data.
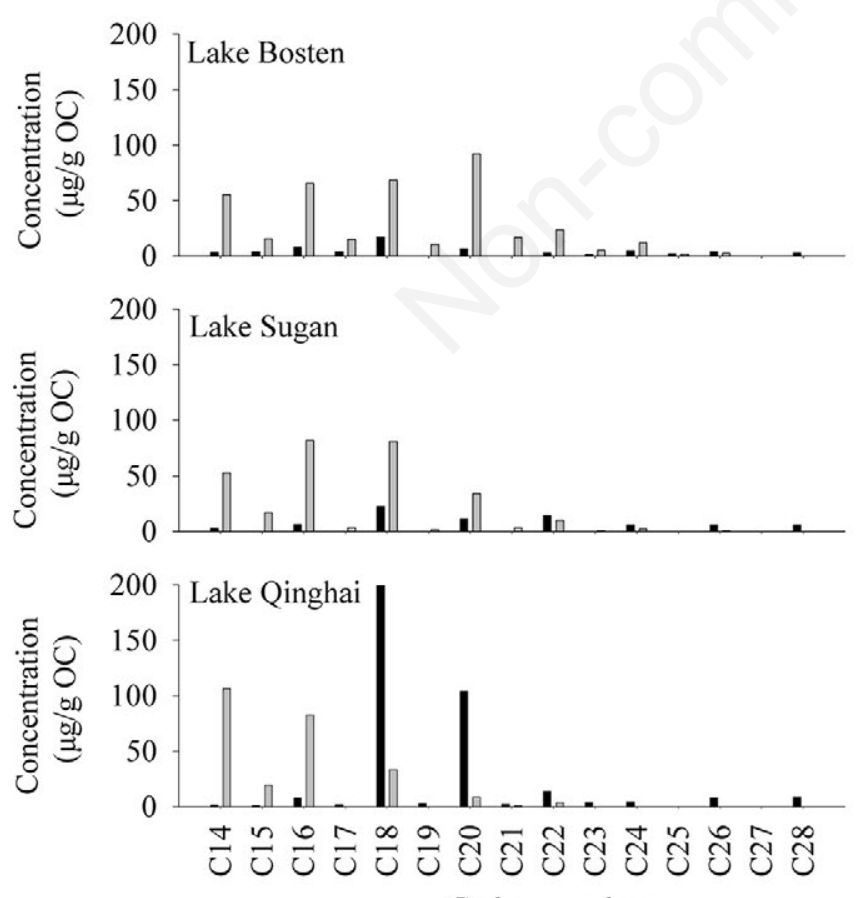

Carbon numbers

Northwestern plateau lakes
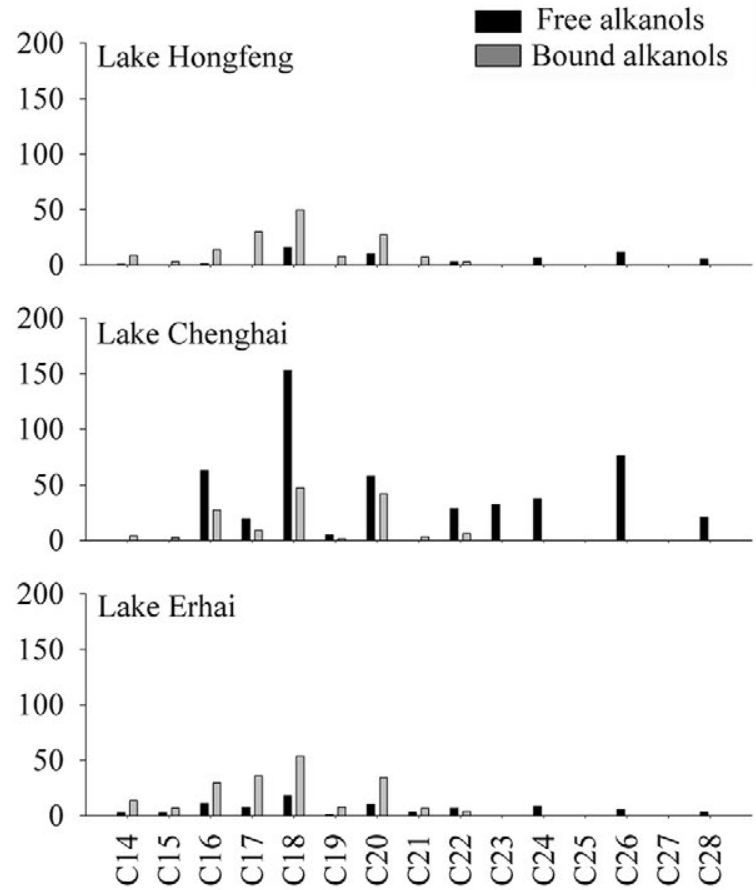

Carbon numbers

Southwestern plateau lakes

Fig. 4. Distribution of $n$-alkanols in the surface sediments. 
and $\mathrm{TAR}_{\mathrm{HC}}$ values are therefore useful in identifying changes in the proportions of terrigenous $v s$ aquatic contributions of hydrocarbons. $\mathrm{TAR}_{\mathrm{HC}}$ ratios are sensitive to contributions to sedimentary OM from vascular plants. Therefore, changes in watershed vegetation that lead to increased contributions from tree and shrub litter cause $\mathrm{TAR}_{\mathrm{HC}}$ values to rise significantly (Silliman et al., 1996). The $\mathrm{TAR}_{\mathrm{HC}}$ ratios showed a decreasing trend from the high-latitude to low-latitude lakes (Tab. 2). This pattern is probably due to the enhanced aquatic production that occurs in lakes at lower latitudes, which causes high aquatic hydrocarbon concentrations and dilutes the terrigenous signal. Low $\mathrm{TAR}_{\mathrm{HC}}$ values indicate a higher proportion of aquatic OM in sediments. More aquatic OM was present in the sediment collected from the southwestern plateau lakes (Tab. 2). These elevated levels of aquatic OM were mainly due to the higher nutrient salt levels, light intensities, and MAWTs in these lakes, which can promote algal and bacterial growth and reproduction (Meseck et al., 2005; Cao et al., 2011). In addition, factors that influence $n$-alkane distributions in lacustrine sediments included ongoing anthropogenic hydrocarbon inputs, such as industrial discharges (from petroleum distribution and refining), shipping activities (dry docking), and sewage outfalls. Secondary $n$-alkanes derived from the decomposition of terrestrial hydrocarbons can also affect $n$-alkane distributions in lacustrine sediments (Meseck et al., 2005; Lü and Zhai, 2006).

The ratios of biomarker FAs can help to summarize the sedimentary FA record. These source identifiers were used to calculate the ratios of terrigenous-to-aquatic FAs, $\mathrm{TAR}_{\mathrm{FA}}=\left(n-\mathrm{C}_{24: 0}+n-\mathrm{C}_{26: 0}+n-\mathrm{C}_{28: 0}\right) /\left(n-\mathrm{C}_{14: 0}+n-\mathrm{C}_{16: 0}+n-\right.$ $\mathrm{C}_{18: 0}$ ). High $\mathrm{TAR}_{\mathrm{FA}}$ values can indicate relatively abundant lipids from terrigenous sources relative to aquatic sources, but they can also indicate degradation of aquatic FAs relative to land-derived components (Tenzer et al., 1999).
Selective degradation and other diagenetic effects commonly overprint FA source signatures. Short-chain acids are often preferentially degraded by microbes during early diagenesis (Ho and Meyers, 1994). This type of preferential degradation increases $\mathrm{TAR}_{\mathrm{FA}}$ values; however, no such elevated values were evident in these sedimentary samples. Microbial synthesis of secondary FAs from primary OM produces shorter-chain components (Kawamura et al., 1987), which can depress $\mathrm{TAR}_{\mathrm{FA}}$ values. All of the $\mathrm{TAR}_{\mathrm{FA}}$ values of the BFAs and FFAs were low (Tab. 2). These low values indicate that either algal contributions were predominant in the FAs, or microbial reworking of sedimentary OM overprinted the original source characteristics of the FA components. Both land-plant and algal FAs would need to have been heavily reworked to yield the low $\mathrm{TAR}_{\mathrm{FA}}$ values found in these sediments.

The $n$-alkanol compositions of algae and bacteria are dominated by $\mathrm{C}_{16}$ to $\mathrm{C}_{22} n$-alkanols (Volkman et al., 1999). $\mathrm{C}_{22}$ and $\mathrm{C}_{24} n$-alkanols are mainly derived from submerged and floating plants (Ficken et al., 1998), and $\mathrm{C}_{22}$ to $\mathrm{C}_{28} n$-alkanols have been found in land and emergent water plants. The $n$-alkanol terrigenous-to-aquatic ratio is defined as $\mathrm{TAR}_{\mathrm{AK}}=\left(\mathrm{C}_{24}+\mathrm{C}_{26}+\mathrm{C}_{28}\right) /\left(\mathrm{C}_{14}+\mathrm{C}_{16}+\mathrm{C}_{18}\right)$. The $\mathrm{TAR}_{\mathrm{AK}}$ values for the sedimentary samples ranged from 0.1 to 1.3 , and these values ranged from 0.0 to 0.1 for free and bound $n$-alkanols, respectively (Tab. 2). The relatively small contributions of the more readily preserved longchain $n$-FAs and alkanols indicate that the initial contributions of land-plant lipids to sedimentary samples were smaller compared with the algal and bacterial contributions. Unlike the general dominance of vascular plant-wax contributions seen in the $\mathrm{TAR}_{\mathrm{HC}}$ values from the northwestern plateau lakes, the $\mathrm{TAR}_{\mathrm{FA}}$ and $\mathrm{TAR}_{\mathrm{AK}}$ values showed that, in general, FAs and $n$-alkanols from aquatic sources were predominant. Since $n$-alkanes are more resistant to microbial degradation than $n$-alkanols and FAs

Tab. 2. Biomarker parameters for aliphatic hydrocarbons (AHs), $n$-alkanols, and fatty acids (FAs).

\begin{tabular}{|c|c|c|c|c|c|c|c|c|c|c|c|c|c|c|c|}
\hline \multirow[t]{4}{*}{ Lake } & \multicolumn{5}{|c|}{ Aliphatic hydrocarbons } & \multicolumn{3}{|c|}{ Alkanols } & \multicolumn{7}{|c|}{ Fatty acids } \\
\hline & \multirow[t]{3}{*}{$\mathrm{TAR}_{\mathrm{HC}}$} & \multirow[t]{3}{*}{$\mathrm{CPI}_{15-20}$} & \multirow[t]{3}{*}{$\mathrm{CPI}_{25-31}$} & \multirow[t]{3}{*}{$\mathrm{C}_{16 \text { ratio }}$} & \multirow[t]{3}{*}{$\mathbf{P r} / \mathbf{P h}$} & \multirow[t]{2}{*}{$\mathrm{CPI}_{16-28}$} & \multicolumn{2}{|c|}{$\mathrm{TAR}_{\mathrm{AK}}$} & $\mathrm{CPI}_{16-28}$ & \multicolumn{2}{|c|}{$\mathrm{TAR}_{\mathrm{FA}}$} & \multirow{2}{*}{\multicolumn{2}{|c|}{$\begin{array}{l}\text { BRFA } \\
\text { /SSFA }\end{array}$}} & \multirow{2}{*}{\multicolumn{2}{|c|}{$\begin{array}{l}\text { MUFA MUF } \\
\text { /SSFA /BRF }\end{array}$}} \\
\hline & & & & & & & & & & & & & & & \\
\hline & & & & & & Free Bound & Free & Bound & Free Bound & Free & Bound & Free & Bound & Bound & Bound \\
\hline Lake Bosten & 2.3 & 1.6 & 5.1 & 22.9 & 0.8 & 4.8 & 0.4 & 0.1 & 8.5 & 0.4 & 0.0 & 0.1 & 0.3 & 0.2 & 0.5 \\
\hline Lake Sugan & 5.7 & 1.5 & 2.9 & 128.0 & 0.2 & 20.0 & 0.5 & 0.0 & 16.2 & 0.1 & 0.0 & 0.2 & 0.5 & 0.2 & 0.4 \\
\hline Lake Qinghai & 2.4 & 1.0 & 5.7 & 36.1 & 0.3 & 131.0 & 0.1 & 0.0 & 17.9 & 0.1 & 0.0 & 0.1 & 0.3 & 0.4 & 1.0 \\
\hline Lake Hongfeng & 1.1 & 1.7 & 4.4 & 12.2 & 0.9 & n. a. & 1.3 & 0.0 & 17.1 & 0.6 & 0.0 & 0.2 & 1.3 & 0.3 & 0.2 \\
\hline Lake Chenghai & 1.1 & 1.0 & 2.8 & 45.7 & 0.7 & 7.0 & 0.6 & 0.0 & 10.5 & 0.5 & 0.2 & 0.2 & 0.4 & 0.4 & 0.8 \\
\hline Lake Erhai & 0.4 & 0.8 & 3.5 & 16.8 & 0.5 & 5.0 & 0.5 & 0.0 & 12.1 & 0.2 & 0.0 & 0.1 & 0.3 & 0.2 & 0.7 \\
\hline
\end{tabular}


(Zhou et al., 2010), we attribute the discrepancies among the $n$-alkane, $n$-alkanol, and FA source patterns in the sedimentary OM to post-depositional alteration of the primary alkanol and FA distributions and at least partial replacement by secondary microbial alkanol and FA biomarkers (Zhou et al., 2010). The short-chain $n$-alkane distributions displayed no significant preference for odd or even numbers of carbons (see the $\mathrm{CPI}_{15-20}$ values shown in Tab. 2) in most of the sedimentary samples. They may be derived from the membrane lipids of microorganisms, fossil fuel inputs, or microbial reworking of plant $n$-alkanes. The carbon preference index $\left(\mathrm{CPI}_{25-31}\right)$ is an indicator of the $n$-alkane source. Hydrocarbons composed of a mixture of compounds originating from land plants show a predominance of odd-numbered carbon chains with $\mathrm{CPI}_{25-31}$ within the range of approximately 5-10 (Jeng, 2006). Higher $\mathrm{CPI}_{25-31}$ values found in sediment indicate a greater contribution from vascular plants (Rieley et al., 1991; Hedges and Prahl, 1993), and $\mathrm{CPI}_{25-31}$ values close to unity may indicate inputs from microorganisms, recycled OM, and/or petroleum (Kennicutt et al., 1987). The $n$-alkane $\mathrm{CPI}_{25-31}$ values in the sedimentary samples were found to vary between 2.9 and 5.7, and they showed an overall decreasing trend from the high-latitude to low-latitude lakes (see $\mathrm{CPI}_{25-31}$ values; Tab. 2). This result indicates that warmer conditions favour greater microbial activity, and it can also be attributed to inputs of petrogenic hydrocarbons from human activities.

As $n-\mathrm{C}_{16}$ is rarely found in biolipids, the $\mathrm{C}_{16}$ ratio, which is defined as the sum of all $n$-alkanes $/ n$ - $\mathrm{C}_{16}$, is usually high $(\approx 50)$ in biogenic materials compared with the relatively low values $(\approx 15)$ observed in petroleum-contaminated samples (Colombo et al., 1989). In the present study, the $\mathrm{C}_{16}$ ratios ranged from 12.2 to 128.0. Lake Erhai and Lake Hongfeng have likely been contaminated by petrogenic hydrocarbons, based on their $\mathrm{CPI}_{25-31}$ values $<3$, $\mathrm{C}_{16}$ ratios $<15$ and lower $\mathrm{CPI}_{15-20}$ values, which are consistent with oil-contaminated sediments (Tab. 2). The lakes that have probably been contaminated by petroleum hydrocarbons are located mainly on the southwestern plateau, where they are subject to influences from anthropogenic activities, leading to larger amounts of industrial effluent and domestic sewage entering these lakes (Wang et al., 2007). In uncontaminated sediments, the $\mathrm{Pr} / \mathrm{Ph}$ ratio is higher than 1, typically between 3 and 5 (Steinhauer and Boehm, 1992). In addition, a $\mathrm{Pr} / \mathrm{Ph}$ ratio less than 1 represents anoxic conditions, while a value greater than 1 reflects oxic conditions (Didyk et al., 1978). The $\mathrm{Pr} / \mathrm{Ph}$ ratios were less than 1 in all of the sedimentary samples examined in this study (Tab. 2), which suggests that the surface sediments are subject to anoxic conditions and/or have received material from petroleum sources.

The characteristic FAs can be used to calculate the relative dominance of different sources in lake sediments.
The proportions of the short-chain saturated fatty acids (SSFAs, $n-\mathrm{C}_{12: 0}-\mathrm{C}_{20: 0}$ ), MUFAs and BRFAs to the total aquatic BFAs vary from 38.8 to $67.3 \%, 7.1$ to $36.5 \%$, and 10.0 to $50.5 \%$, respectively, whereas the proportions of the SSFAs and BRFAs to the total aquatic FFAs are in the range of 78.5 to $94.1 \%$ and 5.9 to $21.5 \%$. Rajendran et al. (1997) found that MUFAs were predominantly present in aerobic bacteria $(60.5 \%)$, whereas anaerobic bacteria and sulfate-reducing bacteria (SRB) contained approximately equal amounts of BRFAs (74.0\% and 78.1\%). In addition, Gram-positive bacteria are also reported to contain high amounts of BRFAs. The predominance of BRFAs and MUFAs in different groups of bacteria suggest that they can be used to determine the relative dominance of these bacterial groups in sediments (Rajendran et al., 1997). The MUFA/BRFA, MUFA/SSFA, and BRFA/SSFA ratios are approximately $9.3,1.8$, and 0.2 for aerobic bacteria, but these ratios are approximately $0.2,1.4$, and 6.8 for anaerobic bacteria, SRB, and Gram-positive bacteria (Rajendran et al., 1997). In this study, the MUFA/BRFA, MUFA/SSFA, and BRFA/SSFA ratios varied from 0.2 to $1.0,0.2$ to 0.4 , and 0.3 to 1.3 for the BFAs, but the BRFA/SSFA ratios ranged from 0.1 to 0.2 for the FFAs (Tab. 2). These results indicate that FAs derived from algae were the dominant components of the aquatic FAs. As previously noted, anoxic conditions in lake sediments may lead to better preservation of some of these algal FAs (Gong and Hollander, 1997), and anaerobic bacteria were the main contributors of FAs from bacterial sources.

Even carbon numbers dominate the FA composition, and $\mathrm{CPI}_{16-28}$ values from 8.5 to 17.1 and from 8.5 to 17.9 were noted in the BFAs and FFAs, respectively (Tab. 2). The $\mathrm{CPI}_{16-28}$ values of the BFAs and FFAs were higher than the $\mathrm{CPI}_{25-31}$ values for the $n$-alkanes. The greater microbial alteration of $n$-alkanes implied by the smaller $n$ alkane CPI values agrees with the larger FA CPI values that signify greater microbial production of secondary acids (Zhou et al., 2010). The MAWT increased gradually as the latitude decreased. A decrease in latitude could lead to greater decomposition of terrigenous $\mathrm{OM}$, as warmer water temperatures would encourage more microbial activity (Zheng et al., 2007). The CPIs summarize the relative proportions of even-numbered and odd-numbered carbon molecules in the FAs and the $n$-alkanol and $n$ alkane distributions of the sedimentary samples. Because the rates of microbial degradation and alteration can differ under non-uniform climate regimes, the CPI values of sediment lipids can reflect relative changes in water temperature. At low water temperatures, microbial degradation and diagenesis of OM are slowed (Kuder and Kruge, 1998), leading to high CPI values. In contrast, low CPI values are evidence of amplified microbial degradation and alteration of $\mathrm{OM}$ in lake sediments corresponding to higher water temperatures. The $n$-alkanol $\mathrm{CPI}_{16-28}$ values 
could not be calculated for free $n$-alkanols in some of the sedimentary samples because of the absence of odd-numbered carbon chains. The $\mathrm{CPI}_{16-28}$ values ranged from 1.9 to 130.9 for the bound $n$-alkanols and from 5.0 to 32.0 for the partially free $n$-alkanols (Tab. 2). Because of the lower MAWT, the $n$-alkanol $\mathrm{CPI}_{16-28}$ values were higher in the sediments obtained from the northwestern plateau lakes.

The apparent differences in the distributions of $n$-alkanes, $n$-alkanols, and FAs likely reflect a combination of continual microbial degradation of FAs and $n$-alkanols in the sediments and partial replacement of originally deposited FAs and $n$-alkanols by secondary, microbial FAs and $n$-alkanols. In contrast, the $n$-alkane concentrations are less likely to be diminished by degradation and are unlikely to be replaced by microbial contributions (Tenzer et al., 1999). There were marked differences in the results from different biomarkers. The FAs and $n$-alkanols suggest that the $\mathrm{OM}$ in most of the sediment samples came mainly from algal and bacterial inputs. However, the $n$ alkane distributions suggest that the OM in the sediments from the northwestern plateau lakes came mostly from terrestrial inputs, while that in the southwestern plateau lakes came mainly from algal and bacterial sources. The differences between the results might be due to the various mechanisms of degradation that affect different biomarkers or a specific input of a certain biomarker; thus, care must be exercised when using a single biomarker as an indicator of OM input.

\section{CONCLUSIONS}

The present study addresses the origin and distribution of dissolvable organic matter found in sediment collected from southwestern and northwestern plateau lakes in China at the level of elements, stable carbon isotopes and molecular compositions. The distributions of the components of free and bound lipid biomarkers suggest that the lipids found in the sediment samples are derived from a mixture of terrigenous and aquatic inputs.

The FAs and $n$-alkanols suggest that the OM in most of the sediment samples originated mainly from algal and bacterial inputs, and the aquatic OM fractions were higher in sediments from the southwestern plateau lakes than from the northwestern plateau lakes. This difference may be due to the higher light intensities and MAWTs in the southwestern lakes, which promote the growth and reproduction of algae and bacteria and simultaneously lead to additional decomposition of terrestrial OM. The OM derived from algae is the major component of sedimentary $\mathrm{OM}$, and anaerobic bacteria are the primary contributors of bacterial OM. The compositions of $n$-alkane biomarkers are well preserved in the sediment samples. However, the $n$-alkanols are not as well preserved, and the original, vascular plant $n$-FAs have been largely replaced by mi- crobial compounds. Components produced by microbial reworking were observed in the bound $n$-alkanols and FAs, but few such components are present in the free $n$ alkanols and FAs.

\section{ACKNOWLEDGMENTS}

This research has been funded by the Programs of Natural Science Foundation of Shandong Province (Grant No. ZR2014DM002) and University Science and Technology Project of Shandong Province (Grant No. J14LD03).

\section{REFERENCES}

Aravena R, Evans ML, Cherry JA, 1993. Stable isotopes of oxygen and nitrogen in source identification of nitrate from septic systems. Ground Water 31:180-186.

Cao CJ, Zheng BH, Chen ZL, Huang MS, Zhang JL, 2011. Eutrophication and algal blooms in channel type reservoirs: A novel enclosure experiment by changing light intensity. J. Environ. Sci. 23:1660-1670.

Colombo JC, Pelletier E, Brochu C, Khalil M, 1989. Determination of hydrocarbon sources using $n$-alkanes and polyaromatic hydrocarbon distribution indices. Case study: Rio de La Plata Estuary, Argentina. Environ. Sci. Technol. 23:888-894.

Didyk BM, Simoneit BRT, Brassell SC, Eglinton G, 1978. Organic geochemical indicators of paleoenvironmental conditions of sedimentation. Nature 272:216-222.

Fang JD, Wu FC, Xiong YQ, Li FS, Du XM, An D, Wang LF, 2014. Source characterization of sedimentary organic matter using molecular and stable carbon isotopic composition of n-alkanes and fatty acids in sediment core from Lake Dianchi, China. Sci.Total.Environ. 473-474:410-421.

Ficken KJ, Barber KE, Eglinton G, 1998. Lipid biomarker, $\delta^{13} \mathrm{C}$ and plant macrofossil stratigraphy of a Scottish montane peat bog over the last two millennia. Org. Geochem. 28: 217-237.

Gong CR, Hollander DJ, 1997. Differential contribution of bacteria to sedimentary organic matter in oxic and anoxic environments, Santa Monica Basin, California. Org. Geochem. 26:545-563.

Hedges JI, Prahl FG, 1993. Early diagenesis: consequences for applications of molecular biomarkers. In: Engel, M.H., Macko, S.A. (Eds.), Organic Geochemistry: principles and applications. Plenum Press, New York:237-253pp.

Ho E, Meyers PA, 1994. Variability of early diagenesis in lake sediments: evidence from the sedimentary geolipid record in an isolated tarn. Chem. Geol. 112:309-324.

Jasper JP, Gagosian RB, 1989. Glacial-interglacial climatically forced $\delta^{13} \mathrm{C}$ variations in sedimentary organic matter. Nature 342:60-62.

Jeng WL, 2006. Higher plant $n$-alkane average chain length as an indicator of petrogenic hydrocarbon contamination in marine sediments. Mar. Chem. 102:242-251.

Kawamura K, Ishiwatari R, Ogura K, 1987. Early diagenesis of organic matter in the water column and sediments: microbial 
degradation and resynthesis of lipids in lake Haruna. Org. Geochem. 11:251-264.

Kennicutt IIMC, Barker C, Brooks JM, DeFreitas DA, Zhu GH, 1987. Selected organic matter source indicators in the Orinoco, Nile and Changjiang deltas. Org. Geochem. 11:41-51.

Kuder T, Kruge MA, 1998. Preservation of biomolecules in subfossil plants from raised peat bogs - a potential paleoenvironmental proxy. Org. Geochem. 29:1355-1368.

Li XZ, Liu WG, Xu LM, 2012. Carbon isotopes in surface-sediment carbonates of modern Lake Qinghai (Qinghai-Tibet Plateau): Implications for lake evolution in arid areas. Chem. Geol. 300-301:88-96.

Lü XX, Zhai SK, 2006. Distributions and sources of organic biomarkers in surface sediments from the Changjiang (Yangtze River) Estuary, China. Cont. Shelf Res. 26:1-14.

Meseck SL, Alix JH, Wikfors GH, 2005. Photoperiod and light intensity effects on growth and utilization of nutrients by the aquaculture feed microalga, Tetraselmis chui (PLY429). Aquaculture 246:393-404.

Meyers PA, 1997. Organic geochemical proxies of paleoceanographic, paleolimnologic, and paleoclimatic processes. Org. Geochem. 27:213-250.

Meyers PA, 2003. Applications of organic geochemistry to paleolimnological reconstructions: a summary of examples from the Laurentian Great Lakes. Org. Geochem. 34:261-289.

Muri G, Simčič T, 2004. Respiratory activity in se0diments in three mountain lakes of the Julian Alps and in subalpine Lake Bled (Slovenia): an effect of altitude and anthropic influence. Aquat. Microb. Ecol. 34:291-299.

Rajendran N, Matsuda O, Rajendran R, Urushigawa Y, 1997. Comparative description of microbial community structure in surface sediments of eutrophic bays. Mar. Pollut. Bull. 34:26-33.

Rieley G, Collier RJ, Jones DM, Eglinton G, 1991. The biogeochemistry of Ellesmere Lake, U.K. - I. Source correlation of leaf wax inputs to the sedimentary lipid record. Org. Geochem. 17:901-912.
Robinson N, Cranwell PA, Finlay BJ, Eglinton G, 1984. Lipids of aquatic organisms as potential contributors tolacustrine sediments. Org. Geochem. 6:143-152.

Silliman JE, Meyers PA, Bourbonniere RA, 1996. Record of postglacial organic matter delivery and burial in sediments of Lake Ontario. Org. Geochem. 24:463-472.

Steinhauer MS, Boehm PD, 1992. The composition and distribution of saturated and aromatic hydrocarbons in nearshore sediments, river sediments, and coastal peat of Alaskan Beaufort Sea: implications for detecting anthropogenic hydrocarbon inputs. Mar. Environ. Res. 33:323-353.

Tenzer GE, Meyers PA, Robbins JA, Eadie BJ, Morehead NR, Lansing MB, 1999. Sedimentary organic matter record of recent environmental changes in the St. Marys River ecosystem, Michigan-Ontario border. Org. Geochem. 30:133-146.

Thornton SF, McManus J, 1994. Application of organic carbon and nitrogen stable isotope and $\mathrm{C} / \mathrm{N}$ ratios as source indicators of organic matter provenance in estuarine systems: Evidence from the Tay Estuary, Scotland. Estuar. Coast Shelf S. 38:219-233

Volkman JK, Barrett SM, Blackburn SI, 1999. Eustigmatophyte microalgae are potential sources of $\mathrm{C}_{29}$ sterols, $n-\mathrm{C}_{23}-n-\mathrm{C}_{28}$ $n$-alkanols and $\mathrm{C}_{28}-\mathrm{C}_{32} n$-alkyl diols in freshwater environments. Org. Geochem. 30:307-318.

Wang XL, Lu YL, Han JY, He GZ, Wang TY, 2007. Identification of anthropogenic influences on water quality of rivers in Taihu watershed. J. Environ. Sci. 19: 475-481.

Xiong YQ, Wu FC, Fang JD, Wang LF, Li Y, Liao HQ, 2010. Organic geochemical record of environmental changes in Lake Dianchi, China. J. Paleolimnol. 44:217-231.

Zheng Y, Zhou WJ, Meyers PA, Xie S, 2007. Lipid biomarkers in the Zoige-Hongyuan peat deposit: indicators of Holocene climate change in west China. Org. Geochem. 38:1927-1940.

Zhou WJ, Zheng YH, Meyers PA, Jull AJT, Xie SC, 2010. Postglacial climate-change record in biomarker lipid compositions of the Hani peat sequence, Northeastern China. Earth. Planet. Sc. Lett. 294:37-46. 